Research Article

Human and Medical Genetics

\title{
The combined risk effect among BIN1, CLU, and APOE genes in Alzheimer's disease
}

\author{
Lígia Ramos dos Santos ${ }^{1 *}$, Jucimara Ferreira Figueiredo Almeida ${ }^{1,2^{*}}$, Lúcia Helena Sagrillo Pimassoni ${ }^{3}$, \\ Renato Lírio Morelato ${ }^{3,4}$ and Flavia de Paula ${ }^{1,2^{*}}$ (1) \\ ${ }^{1}$ Universidade Federal do Espírito Santo, Centro de Ciências Humanas e Naturais, Departamento de \\ Ciências Biológicas, Núcleo de Genética Humana e Molecular, Vitória, ES, Brazil. \\ ${ }^{2}$ Universidade Federal do Espírito Santo, Programa de Pós-Graduação em Biotecnologia, Vitória, ES, \\ Brazil. \\ ${ }^{3}$ Escola Superior de Ciências da Santa Casa de Misericórdia de Vitória, Vitória, ES, Brazil. \\ ${ }^{4}$ Hospital da Santa Casa de Misericórdia de Vitória, Escola Superior de Ciências da Santa Casa de \\ Misericórdia de Vitória, Vitória, ES, Brazil.
}

\begin{abstract}
Genome-wide associations studies (GWAS) are detecting new variants associated with late-onset of Alzheimer's disease (LOAD), a multifactorial neurodegenerative disorder. The variants rs744373 BIN1, rs11136000 CLU and rs3764650 ABCA7 uncovered by GWAS led to different AD pathways, such as metabolism, trafficking and endocytosis of lipids and inflammation. However, most of the association studies did not replicate these variants with significance. This could be due to a small power effect evident when these variants are tested independently with LOAD. Therefore, we aimed to investigate whether the combination of different variants would additively modify the risk of association with LOAD that is observed in GWAS. We performed an association study testing pairwise variants in metabolism, trafficking and endocytosis of lipid (rs429358 and rs7412 APOE, rs744373 BIN1, rs3764650 $A B C A 7$ and rs $11136000 C L U$ ) pathways with LOAD in samples from southeastern Brazil. Our data suggest a risk effect for LOAD between APOE with CLU and APOE with BIN1 genes.
\end{abstract}

Keywords: GWAS variants, APOE, CLU, BIN1, ABCA7.

Received: October 30, 2018; Accepted: April 11, 2019.

\section{Introduction}

Alzheimer's disease (AD) is a neurodegenerative disease that affects millions of elders globally (Prince et al., 2016). Familial, or early-onset AD (EOAD), accounts for $2 \%$ of $\mathrm{AD}$ cases and occurs before 65 years. EOAD has Mendelian patterns of inheritance, with mutations in $A P P$ (amyloid precursor protein), PSEN1 (presenilin 1) and PSEN2 (presenilin 2) genes (Bertram et al., 2010; Holtzman et al., 2011). Unlike EOAD, late-onset AD (LOAD) has a multifactorial pattern, with influence of genetic and environmental factors. It occurs after 65 years and accounts for $98 \%$ of AD cases (Yu et al., 2014). To date, the $\varepsilon 4$ allele in the apolipoprotein $\mathrm{E}(A P O E)$ gene is considered a major

Send correspondence to Flavia de Paula. Universidade Federal do Espírito Santo, Laboratório de Genética Humana e Molecular, Departamento de Ciências Biológicas, CCHN, Av. Fernando Ferrari, 514, 29075-910 Vitória, ES, Brazil. E-mail: flapvit@yahoo.com.br.

*These authors contributed equally to this study. risk factor for LOAD worldwide (Lambert and Amouyel, 2011).

The main hypothesis regarding neurodegeneration in $\mathrm{AD}$ is that the amyloid cascade leads to amyloid plaque formation (Heppner et al., 2015). This event occurs due to the impaired degradation of neurotoxic $A \beta 42$ peptides. Both the increased formation and the decrease in the clearance of A $\beta 42$ peptides, is considered to play a role in the development of $\mathrm{AD}$. Recent studies suggest that cholesterol is a part of the regulation in the clearance of $A \beta 42$ peptides formed in the brain (Kojro et al., 2001; O'Brien et al., 2011; Reitz, 2013). In neurons, cholesterol is vital for function and plasticity. Function and plasticity are important in the process of learning and memory formation, all of which are found to be impaired in AD (Pfrieger, 2003). Moreover, several genes beyond APOE have been implicated in alterations in cholesterol metabolism, trafficking and endocytosis, such as Clusterin (CLU), Bridging integrator 1 (BINI) and the ATP-binding cassette transporter A7 ( $A B C A 7)$ genes, all variants that have been identified in genome-wide associa- 
tions studies (GWAS) (Harold et al., 2009; Lambert et al., 2009; Hollingworth et al., 2011; Naj et al., 2011; Karch and Goate, 2014). Most of the GWAS variants associated with LOAD have small effects individually (Ebbert et al., 2015). In addition, the case-control studies that replicated those variants did not all reach significance. In this scenario, the nonsignificance may be due to a lack of the power effect of those variants when tested independently with LOAD. It is possible that a combination of different variants together would enhance the effect of association with LOAD that is observed in GWAS. Therefore, the main goal of this study was to test pairwise variants from metabolism, trafficking and endocytosis of lipid (rs429358 and rs7412 APOE, rs744373 BIN1, rs3764650 ABCA7 and rs11136000 CLU) pathways with late-onset $\mathrm{AD}$ in a sample from southeastern Brazil.

\section{Subjects and Methods}

\section{Subjects}

This is an association study with 224 unrelated individuals. We selected 79 elderly patients diagnosed for probable AD with LOAD according to the criteria of the National Institute of Neurological and Communicative Disorders and Stroke and the Alzheimer disease and Related Disorders Association (NINCDS-ADRDA). These patients had a comprehensive diagnostic evaluation for dementia and fulfill other criteria, such as the Mini-Mental State Examination (MMSE). For controls, 145 healthy elderly patients were selected, and all were matched for sex and age. Demographic and clinical data of the sample composition is presented in Table 1. Our recent study (dos Santos et al., 2017) demonstrated that our sample had no difference for variables, such as gender $(p=0.536)$, ethnic background $(p=0.641)$, schooling $(p=0.281)$ and age $(p=0.144)$, except for APOE status $(p<0.001)$, among AD cases and controls.

All the participants in this research resided in the metropolitan region of Espírito Santo, Grande Vitória, in southeastern Brazil. They were assisted by a geriatrician at the Geriatric Unit of the Hospital Santa Casa de Misericórdia de Vitória (HSCMV) and Centro de Atendimento ao Idoso (CRAI), ES, Brazil. Additionally, the participants or their relatives gave written informed consent agreeing to participate in the research study. Information regarding age, gender, ethnic background composition and schooling was collected. The geriatrician meticulously selected only participants with no family history of Alzheimer's. This study was accepted by the Committee of Ethics in Human Research of Escola Superior de Ciências da Santa Casa de Misericórdia de Vitória, Brazil.

\section{Blood sampling and genotyping}

Peripheral blood was collected into a $5 \mathrm{~mL}$ tube with $5 \%$ ethylene diamine tetraacetic acid (EDTA) at the Geriatric Unit of HSCMV and CRAI. The samples were stored at
Table 1 - Sample characteristics.

\begin{tabular}{|c|c|c|}
\hline Variable & $\begin{array}{c}\text { Controls } 145 \\
(100 \%)\end{array}$ & $\begin{array}{c}\text { AD Patients } 79 \\
(100 \%)\end{array}$ \\
\hline \multicolumn{3}{|l|}{ Gender } \\
\hline Woman & $106(73.1 \%)$ & $54(68.4 \%)$ \\
\hline Man & $39(26.9 \%)$ & $25(31.6 \%)$ \\
\hline \multicolumn{3}{|l|}{ Ethnic background } \\
\hline Caucasians & $83(57.2 \%)$ & $45(57.0 \%)$ \\
\hline Afro-Brazilians & $60(41.4 \%)$ & $34(43.0 \%)$ \\
\hline No identification & $2(1.4 \%)$ & 0 \\
\hline \multicolumn{3}{|l|}{ Schooling } \\
\hline Literate & $94(64.8 \%)$ & $41(51.9 \%)$ \\
\hline Illiterate & $45(31.0 \%)$ & $28(35.4 \%)$ \\
\hline No identification & $6(4.1 \%)$ & $10(12.7 \%)$ \\
\hline \multicolumn{3}{|l|}{ APOE status } \\
\hline$\varepsilon 4-$ & $102(70.3 \%)$ & $35(44.3 \%)$ \\
\hline$\varepsilon 4+$ & $43(29.7 \%)$ & $44(55.7 \%)$ \\
\hline Age (mean and SD) & $80,1 \pm 7,8$ & $81,6 \pm 7$ \\
\hline MMSE & $>28$ & 14-4 \\
\hline
\end{tabular}

$\mathrm{AD}$ Patients $=$ Alzheimer's disease patients; $\varepsilon 4+=\varepsilon 4$ carriers; $\varepsilon 4-=\varepsilon 4$ non-carriers; $\mathrm{SD}=$ standard deviation; Mini-Mental State Examination (MMSE).

$4{ }^{\circ} \mathrm{C}$ prior to analyses. Genomic DNA was isolated according to previous methodology (Miller et al., 1988). We calculated the adequate sample size using the proportion of the genes in the population based on the overall frequency of the minor alleles of each polymorphism. The estimate of adequate sample size for the $A P O E$ gene and $A B C A 7$ polymorphisms was 207 , and for the $C L U$ and $B I N 1$ genes it was 377 individuals. Therefore, our results are consistent since our sample contained 224 individuals.

Genotyping was performed by our previous coworkers (Almada et al., 2012; Belcavello et al., 2015; dos Santos et al., 2016, 2017) using the Brazilian sample set of this study. The variant rs3764650 ABCA7 was performed by Santos et al. (2017) through real time - polymerase chain reaction (qPCR), and the three standard genotypes were confirmed by Sanger sequencing. Analysis of the variants rs744373 BIN1, rs11136000 $C L U$ and (rs429358 and rs7412) $A P O E$ were performed, respectively, by Almada et al. (2012), Belcavello et al. (2015) and dos Santos et al. (2016) thought restriction fragment length polymorphism polymerase chain reaction (RFLP-PCR).

\section{Statistical analysis}

All the statistical analyses were performed using SPSS (IBM) software v.23.0 for Windows. A $p$-value $\leq$ 0.05 was considered significant.

Logistic regression analysis was performed for each single nucleotide polymorphism (SNP) and for allelic combinations between two polymorphisms. The $p$-value was 
adjusted using $A P O E$ status, age, gender, school level and ethnic background as variables. For education, was considered literate or illiterate. For $A P O E$ status, was considered an $\varepsilon 4+$ for those that carried at least one $\varepsilon 4$ allele; and $\varepsilon 4$-, for those that carried no $\varepsilon 4$ allele. The $p$-value in $A P O E$ association with LOAD when pairwise with another variant, or not combined, was not adjusted for $A P O E$ status. The allelic combinations tested followed genes from lipid metabolism and the endocytosis pathway ( $A B C A 7, C L U, B I N 1$ and $A P O E$ ). The allele frequencies of SNPs were inferred from the following studies: dos Santos et al. (2017) for rs3764650 ABCA7; dos Santos et al. (2016) for rs744373 BIN1, Belcavello et al. (2015) for rs11136000 CLU, and Almada et al. (2012) for rs429358 and rs7412 APOE.

\section{Results}

Results of the test of independent association for LOAD of $C L U$ (rs11136000), ABCA7 (rs3764650), BIN1 (rs744373) and $A P O E$ (rs429358 and rs7412) are presented in Table 2. As expected, the $\varepsilon 4$ allele in $A P O E$ was statistically significant. No association was observed for LOAD for the $\mathrm{G}$ allele in $A B C A 7$, the $\mathrm{T}$ allele in $C L U$ and the $\mathrm{C}$ allele in BIN1 genes.

The data of combined allelic variants are presented in Table 3. A significant association was not observed between $C L U$ and $A B C A 7, C L U$ and BIN1 or $A B C A 7$ and $B I N 1$. The presence of the $\varepsilon 4$ allele in $A P O E$ alone was associated with LOAD in the absence of the minor $\mathrm{G}$ allele $A B C A 7(p<0.001)$, the absence of the minor $\mathrm{C}$ allele in $B I N 1(p<0.001)$ and the T allele in $C L U(p=0.030)$, also after p-value adjustment. The presence of the $\mathrm{C}$ allele in BIN1 and the $\varepsilon 4$ allele in $A P O E$ showed risk for LOAD (OR =
$3.489)$, even after $p$-value adjustment $(\mathrm{OR}=3.678)$. The presence of both $\mathrm{T}$ alleles in $C L U$ and the $\varepsilon 4$ allele in $A P O E$ enhances the risk 3.911-fold for LOAD and after $p$-value adjustment $(\mathrm{OR}=3.633)$. However, no association was found between the $\varepsilon 4$ allele in $A P O E$ and the $\mathrm{G}$ allele in $A B C A 7(p=0.128)$ and after $p$-value adjustment $(p=0.115)$.

\section{Discussion}

LOAD studies of additive combinations of genetic variants are scarce, and most of those published articles had non-GWAS variants. In this study, we aimed to investigate GWAS variants combined and with the $A P O E$ gene as well, for late-onset $\mathrm{AD}$ in samples from southeastern Brazil. Among the combination tested, we found a risk for LOAD between $C L U$ and $A P O E$ and between BIN1 and $A P O E$ genes.

The Apolipoprotein E $(A P O E)$ gene is localized at chromosome region $19 \mathrm{q} 13.2$ and encodes the APOE protein, an apolipoprotein (Morgan and Carrasquillo, 2013). Due to the SNPs rs429358 and rs7412 in the APOE gene, three haplotypes are formed: $\varepsilon 2$ ( $\mathrm{T}$ allele rs7412 and T allele rs429358), $\varepsilon 3$ (C allele rs7412 and T allele rs429358), and the $\varepsilon 4$ allele (C allele rs7412 and $C$ allele rs429358) (Morgan and Carrasquillo, 2013). The APOE protein and Clusterin (CLU) protein, another apolipoprotein, carries cholesterol among brain cells (El Gaamouch et al., 2016) and acts on the clearance of A $\beta$ peptides (Rizzi et al., 2009). The CLU or Apolipoprotein J (APOJ) protein (Rizzi et al., 2009) is associated with a neuroprotective effect in AD (Schrijvers et al., 2011). APOJ is encoded by the Clusterin (CLU) gene, located at chromosome 8p21.1 (Schrijvers et al., 2011). The $C L U$ gene has the T allele from the poly-

Table 2 - Test for independent interaction of SNPs with LOAD.

\begin{tabular}{|c|c|c|c|c|c|c|}
\hline Polymorphism & AD Patients N (\%) & $\begin{array}{c}\text { Controls N } \\
(\%)\end{array}$ & OR (95\% IC) & $p$-value ${ }^{\mathrm{a}}$ & OR (95\% IC) & $p$-value ${ }^{\mathrm{b}}$ \\
\hline \multicolumn{7}{|l|}{$A B C A 7(\mathrm{rs} 3764650)$} \\
\hline $\mathrm{T}$ & $52(68.4 \%)$ & $105(75.5 \%)$ & 1 (Reference) & - & 1 (Reference) & - \\
\hline G & $24(31.6 \%)$ & $34(24.5 \%)$ & $1.425(0.767-2.648)$ & 0.262 & $1.552(0.794-3.037)$ & 0.199 \\
\hline \multicolumn{7}{|l|}{$C L U(\operatorname{rs} 11136000)$} \\
\hline $\mathrm{C}$ & $89(57.1 \%)$ & $170(58.6 \%)$ & 1 (Reference) & - & 1 (Reference) & - \\
\hline $\mathrm{T}$ & $67(42.9 \%)$ & $120(41.4 \%)$ & $0.938(0.632-1.390)$ & 0.764 & $0.840(0.537-1.314)$ & 0.445 \\
\hline \multicolumn{7}{|l|}{ BIN1 (rs744373) } \\
\hline $\mathrm{T}$ & $106(67.1 \%)$ & $186(65 \%)$ & 1 (Reference) & - & 1 (Reference) & - \\
\hline $\mathrm{C}$ & $52(32.9 \%)$ & $100(35 \%)$ & $0.912(0.605-1.377)$ & 0.662 & $0.960(0.606-1.520)$ & 0.861 \\
\hline \multicolumn{7}{|c|}{$A P O E(\mathrm{rs} 429358, \mathrm{rs} 7412)$} \\
\hline$\varepsilon 4-$ & $103(65.2 \%)$ & $245(84.5 \%)$ & 1 (Reference) & - & 1 (Reference) & - \\
\hline$\varepsilon 4+$ & $55(34.8 \%)$ & $45(15.5 \%)$ & $2.907(1.842-4.588)$ & $<0.001$ & $3.029(1.873-4.898)$ & $<0.001^{\mathrm{c}}$ \\
\hline
\end{tabular}

$\varepsilon 4-=\varepsilon 4$ non-carriers; $\varepsilon 4+=\varepsilon 4$ carriers; AD Patients = Alzheimer's disease patients; $\mathrm{OR}=$ odds ratio; $\mathrm{CI}=$ confidential interval; $p$-value considerer $\leq$ $0.05 ;{ }^{\mathrm{a}}=$ crude $p$-value $;{ }^{\mathrm{b}}=p$-value adjusted by the variables age, gender, educational attainment, ethnic background and APOE $\varepsilon 4$ status; ${ }^{\mathrm{c}}=p$-value adjusted by the variables on ${ }^{\mathrm{b}}$ except for APOE $\varepsilon 4$ status. 
Table 3 - Combined allelic effect among variants in the study.

\begin{tabular}{|c|c|c|c|c|c|c|c|}
\hline Genes & & AD Patients N (\%) & $\begin{array}{c}\text { Controls N } \\
(\%)\end{array}$ & OR $(95 \%$ IC) & $p$-value ${ }^{\mathrm{a}}$ & OR $(95 \%$ IC) & $p$-value $\mathrm{e}^{\mathrm{b}}$ \\
\hline$A B C A 7(\mathrm{G})$ & $A P O E(\varepsilon 4)$ & & & & & & \\
\hline- & - & $88(57.1 \%)$ & $213(73.9 \%)$ & 1 (Reference) & - & 1 (Reference) & - \\
\hline- & + & $40(26 \%)$ & $31(10.8 \%)$ & $3.123(1.837-5.310)$ & $<0.001$ & $3.459(1.977-6.052)$ & $<0.001$ \\
\hline+ & - & $15(9.8 \%)$ & $30(10.4 \%)$ & $1.210(0.621-2.360)$ & 0.575 & $1.391(0.702-2.755)$ & 0.344 \\
\hline+ & + & $11(7.1 \%)$ & $14(4.9 \%)$ & $1.902(0.831-4.352)$ & 0.128 & $2.014(0.844-4.806)$ & 0.115 \\
\hline$B I N 1(\mathrm{C})$ & $A P O E(\varepsilon 4)$ & & & & & & \\
\hline- & - & $61(38.6 \%)$ & $149(52.1 \%)$ & 1 (Reference) & - & 1 (Reference) & - \\
\hline- & + & $45(28.5 \%)$ & $37(13.0 \%)$ & $2.971(1.753-5.033)$ & $<0.001$ & $3.376(1.926-5.918)$ & $<0.001$ \\
\hline+ & - & $42(26.6 \%)$ & $93(32.5 \%)$ & $1.103(0.689-1.766)$ & 0.683 & $1.313(0.788-2.187)$ & 0.297 \\
\hline+ & + & $10(6.3 \%)$ & $7(2.4 \%)$ & 3.489 (1.270-9.588) & 0.015 & $3.678(1.275-10.616)$ & 0.016 \\
\hline$C L U(\mathrm{~T})$ & $A P O E(\varepsilon 4)$ & & & & & & \\
\hline- & - & $57(36.5 \%)$ & $138(47.6 \%)$ & 1 (Reference) & - & 1 (Reference) & - \\
\hline- & + & $32(20.5 \%)$ & $32(11 \%)$ & $2.421(1.357-4.320)$ & 0.030 & $2.664(1.450-4.893)$ & 0.020 \\
\hline+ & - & $46(29.5 \%)$ & $107(36.9 \%)$ & $1.041(0.655-1.654)$ & 0.860 & $1.055(0.640-1.741)$ & 0.834 \\
\hline+ & + & $21(13.5 \%)$ & $13(4.5 \%)$ & $3.911(1.834-8.341)$ & $<0.001$ & $3.633(1.628-8.107)$ & 0.020 \\
\hline BINI (C) & $A B C A 7(\mathrm{G})$ & & & & & & \\
\hline- & - & $79(51.3)$ & $148(52.1)$ & 1 (Reference) & - & 1 (Reference) & - \\
\hline- & + & $24(15.6)$ & $36(12.7)$ & $1.249(0.696-2.240)$ & 0.456 & $1.474(0.786-2.770)$ & 0.226 \\
\hline+ & - & $49(31.8)$ & $94(33.1)$ & $0.977(0.629-1.517)$ & 0.916 & $1.077(0.658-1.763)$ & 0.768 \\
\hline+ & + & $2(1.3)$ & $6(2.1)$ & $0.624(0.123-3.166)$ & 0.570 & $0.824(0.148-4.586)$ & 0.825 \\
\hline$B I N 1$ (C) & $C L U(\mathrm{~T})$ & & & & & & \\
\hline- & - & $66(42.3)$ & $129(45.1)$ & 1 (Reference) & - & 1 (Reference) & - \\
\hline- & + & $38(24.4)$ & $57(19.9)$ & $1.303(0.785-2.162)$ & 0.306 & $1.002(0.565-1.775)$ & 0.995 \\
\hline+ & - & $23(14.7)$ & $38(13.3)$ & $1.183(0.651-2.149)$ & 0.581 & $1.336(0.691-2.584)$ & 0.389 \\
\hline+ & + & $29(18.6)$ & $62(21.7)$ & $0.914(0.517-1.555)$ & 0.741 & $0.786(0.431-1.435)$ & 0.433 \\
\hline$A B C A 7(\mathrm{G})$ & $C L U(\mathrm{~T})$ & & & & & & \\
\hline- & - & $67(43.5)$ & $131(45.5)$ & 1 (Reference) & - & 1 (Reference) & - \\
\hline+ & - & $22(14.3)$ & 37 (12.9) & $1.163(0.635-2.127)$ & 0.625 & $1.375(0.715-2.641)$ & 0.340 \\
\hline- & + & $61(39.6)$ & $113(39.2)$ & $1.055(0.688-1.620)$ & 0.805 & $0.914(0.562-1.486)$ & 0.717 \\
\hline+ & + & $4(2.6)$ & $7(2.4)$ & $1.117(0.316-3.952)$ & 0.863 & $0.719(0.190-2.719)$ & 0.627 \\
\hline
\end{tabular}

$+/$ - = allelic presence $/$ allelic absence; $\mathrm{AD}$ Patients $=$ Alzheimer's disease patients; $\mathrm{OR}=$ odds ratio $\mathrm{CI}=$ confidential interval; $\mathrm{p}$-value considerer $\leq 0.05$;

${ }^{\mathrm{a}}=$ crude $p$-value; ${ }^{\mathrm{b}}=p$-value adjusted by the variables age, gender, educational attainment and ethnic background.

morphism rs11136000 as a protective factor associated with LOAD in the later GWAS (Harold et al., 2009; Lambert et al., 2009). We found that the $\mathrm{T}$ allele in the rs11136000 CLU gene is not related to LOAD independently. Our result is corroborated with the new association studies (Tan et al., 2016; Shankarappa et al., 2017) of rs 11136000 that did not find an association for LOAD in a population of 407 individuals from India (Shankarappa et al., 2017), and 329 individuals from United States (Tan et al., 2016). In combined variant tests, we found that the $\mathrm{T}$ allele in rs $11136000 C L U$ in combination with the $\varepsilon 4$ allele in APOE, enhances the odds of risk for LOAD. A possible explanation is that the rs 11136000 variant may be underpowered alone in our sample and when in a combination with the $\varepsilon 4$ allele in APOE. This variant may modulate the protectiveness aspect in carriers of the $\mathrm{T}$ allele in order to favor risk for $\mathrm{AD}$. We believe that both genes may have functional implications in AD pathology. For instance, studies have shown that the lipidated APOE and CLU proteins can bind to $\mathrm{A} \beta$ peptides individually to direct them to clearance in the brain (Tokuda et al., 2000). Additionally, another study demonstrated that in PDAPP transgenic mice, the absence of APOE and CLU proteins affects the clearance of A $\beta$ peptides (DeMattos et al., 2004). This suggests that $A P O E$ and $C L U$ genes may regulate this function together.

The Bridging integrator 1 (BIN1) gene is located at chromosome 2q14.3 and has the SNP rs744373 associated as a risk factor to LOAD (Harold et al., 2009). The BIN1 
gene encodes the BIN1 protein, which is related to intracellular endosome trafficking of lipids and clathrin mediated endocytosis (Pant et al., 2009). In AD, BIN1 may impact trafficking and endocytosis of cholesterol in the brain and the clearance of $A \beta$ peptides, since it may not internalize with efficiency (Pant et al., 2009; Dong et al., 2017). In our data, the $C$ allele in BIN1 is not independently associated with LOAD. This result is also observed in the work of Hohman et al. (2013) in a population from United States $(\mathrm{n}=235)$ and in Li et al. (2015) in a study of the Han Chinese population $(\mathrm{n}=554)$. In our work, the combination of the $\mathrm{C}$ allele of rs $744373 \mathrm{BIN} 1$ and the $\varepsilon 4$ allele of APOE is risk association $(p=0.015)$ for LOAD. We believe that $B I N 1$ and $A P O E$ may have a possible relation in AD. The study of Lazaris et al. (2015), for example, reported that the CC genotype in rs 744373 BIN1 modulates the association between plasma levels of APOE and brain amyloidosis, which implies evidence of the interaction between the BINI and $A P O E$ genes.

The SNP rs 3764650 in the $A B C A 7$ gene was reported by GWAS to be a risk factor for LOAD (Hollingworth et al., 2011). The ATP-binding cassette transporter A7 $(A B C A 7)$ gene is a member of the $\mathrm{ABC}$ transporters and is located at chromosome 19p13.3. This gene encodes the ABCA7 protein, which actively translocates lipids, such as cholesterol, through cell membranes to APOE and lipidated APOE (Abe-Dohmae et al., 2004; Vasiliou et al., 2009). In the present study, the $\mathrm{G}$ allele in $\mathrm{rs} 3764650 A B C A 7$ is not associated with LOAD, neither separately nor in combination with the $\varepsilon 4$ allele in $A P O E$ genes. A study by Yamazaki et al. (2017) of 100 Japanese patients, and a study by Hohman et al. (2013) consisting of 238 American patients also did not find independent association with LOAD. Although our data found no relation of $A P O E$ with the $A B C A 7$ gene, studies support a role for $A B C A 7$ in lipidation of the APOE protein with cholesterol and $A \beta$ peptide clearance in the pathogenesis of $\mathrm{AD}$ (Kim et al., 2008). For instance, an in vitro study by Chan et al. (2008) reported that $A B C A 7$ stimulates cholesterol efflux to $A P O E$, and can suppresses $\mathrm{A} \beta$ production.

Our work found that the gene combinations of $C L U$ with $A P O E$ and $B I N 1$ with $A P O E$ additively modify the risk of association with LOAD. However, we cannot ignore the possibility of a false positive result. This is due to the overpowering effect of $\& 4 A P O E$ alone, disregarding the gene combination. Nevertheless, the possibility of a falsepositive result is little plausible, since we did not find an association of the $\varepsilon 4$ allele in $A P O E$ with the $\mathrm{G}$ allele in $A B C A 7$. Regarding the data of combined variants that had no association for LOAD in our data, the Brazilian population is a combination of Iberian Caucasians, West Africans, and Native Americans (Lins et al., 2010; Pena et al., 2011). Such ethnic profiles might be responsible for different allele frequencies that may favor risk factors in each popula- tion. Moreover, late-onset AD is a complex disease with diverse components in its interactions, such as epigenetics, age, environment, sex, and genetics (Combarros et al., 2009). With respect to genetic factors, no single polymorphism can fully explain the disease (Dong et al., 2017). Rather, it is a combination of gene variants that may enlighten the concepts of susceptibility to $\mathrm{AD}$ (Vepsäläinen et al., 2009). We believe our results are important to enhance the understanding in the underling etiology of the disease and establishment of novel therapeutic approaches for AD.

\section{Conclusion}

Our data suggest that combinations of variants in $C L U$ with $A P O E$ and $B I N 1$ with $A P O E$ genes are associated with LOAD in the southeast Brazilian population.

\section{Acknowledgments}

We treasured the support of the researchers from the Núcleo de Genética Humana e Molecular- NGHM. This study was financially supported by the Universidade Federal do Espírito Santo (UFES), FAPES/Decit/SCTIE/MS, FACITEC, MCTI, CNPQ, and CAPES (Finance Code 001).

\section{Conflict of interest}

The authors declare no conflicts of interest.

\section{Author Contributions}

LRS, JFFA and FP wrote the manuscript. RLM was the physician in the study; he assisted with the clinical assessment of the recruited participants in the study. LHSP contributed to statistical analyses. All of the authors assisted, read and approved the manuscript before submission.

\section{References}

Abe-Dohmae S, Ikeda Y, Matsuo M, Hayashi M, Okuhira KI, Ueda K and Yokoyama S (2004) Human ABCA7 supports apolipoprotein-mediated release of cellular cholesterol and phospholipid to generate high density lipoprotein. J Biol Chem 279:604-611.

Almada BVP, De-Almeida LD, Camporez D, De-Moraes MVD, Morelato RL, Perrone AMS, Belcavello L, Louro ID and De-Paula F (2012) Protective effect of the APOE-e3 allele in Alzheimer's disease. Braz J Med Biol Res 45:8-12.

Belcavello L, Camporez D, Almeida LD, Morelato RL, Batitucci MCP and de Paula F (2015) Association of MTHFR and PICALM polymorphisms with Alzheimers disease. Mol Biol Rep 42:611-616.

Bertram L, Lill CM and Tanzi RE (2010) The genetics of Alzheimer disease: Back to the future. Neuron 68:270-281.

Chan SL, Kim WS, Kwok JB, Hill AF, Cappai R, Rye KA and Garner B (2008) ATP-binding cassette transporter A7 regulates processing of amyloid precursor protein in vitro. $\mathrm{J}$ Neurochem 106:793-804. 
Combarros O, Cortina-Borja M, Smith AD and Lehmann DJ (2009) Epistasis in sporadic Alzheimer's disease. Neurobiol Aging 30:1333-1349.

DeMattos RB, Cirrito JR, Parsadanian M, May PC, O'Dell MA, Taylor JW, Harmony JAK, Aronow BJ, Bales KR, Paul SM et al. (2004) ApoE and clusterin cooperatively suppress A $\beta$ Levels and deposition: evidence that ApoE regulates extracellular A $\beta$ metabolism in vivo. Neuron 41:193-202.

Dong HK, Gim JA, Yeo SH and Kim HS (2017) Integrated late onset Alzheimer's disease (LOAD) susceptibility genes: Cholesterol metabolism and trafficking perspectives. Gene 597:10-16.

dos Santos LR, Belcavello L, Camporez D, Iamonde MMC, Zandonade E, Lírio MR, Imbroisi VEF, Drumond LI, Do Carmo PBM and de Paula F (2016) Association study of the BIN1 and IL-6 genes on Alzheimer's disease. Neurosci Lett 614:65-69.

dos Santos LR, Pimassoni LHS, Sena GGS, Camporez D, Belcavello L, Trancozo M, Morelato RL, Errera FIV, Bueno MRP and de Paula F (2017) Validating GWAS variants from microglial genes implicated in Alzheimer's disease. J Mol Neurosci 62:215-221.

Ebbert MTW, Ridge PG and Kauwe JSK (2015) Bridging the gap between statistical and biological epistasis in Alzheimer's disease. BioMed Res Int 2015:1-7.

El Gaamouch F, Jing P, Xia J and Cai D (2016) Alzheimer's disease risk genes and lipid regulators. J Alzheimers Dis 53:15-29.

Harold D, Abraham R, Hollingworth P, Sims R, Hamshere M, Pahwa JS, Moskvina V, Williams A, Jones N, Thomas C et al. (2009) Genome-wide association study identifies variants at CLU and PICALM associated with Alzheimer's disease, and shows evidence for additional susceptibility genes. Nat Genet 41:1088-1093.

Heppner FL, Ransohoff RM and Becher B (2015) Immune attack: The role of inflammation in Alzheimer disease. Nat Rev Neurosci 16:358-372.

Hohman TJ, Koran ME and Thornton-Wells T (2013) Epistatic genetic effects among alzheimer's candidate genes. PLoS One 8:e80839.

Hollingworth P, Harold D, Sims R, Gerrish A, Lambert JC, Carrasquillo MM, Abraham R, Hamshere ML, Pahwa JS, Moskvina V et al. (2011) Common variants at ABCA7, MS4A6A/MS4A4E, EPHA1, CD33 and CD2AP are associated with Alzheimer's disease. Nat Genet 43:429-435.

Holtzman DM, Morris JC and Goate AM (2011) Alzheimer's disease: The challenge of the second century. Sci Translat Med 3:77sr1.

Karch CM and Goate AM (2014) Alzheimer's disease risk genes and mechanisms of disease pathogenesis. Biol Psychiatry 77:43-51

Kim WS, Weickert CS and Garner B (2008) Role of ATP-binding cassette transporters in brain lipid transport and neurological disease. J Neurochem 104:1145-1166.

Kojro E, Gimpl G, Lammich S, Marz W and Fahrenholz F (2001) Low cholesterol stimulates the nonamyloidogenic pathway by its effect on the -secretase ADAM 10. Proc Nartl Acad Sci U S A 98:5815-5820.

Lambert JC and Amouyel P (2011) Genetics of Alzheimer's disease: New evidences for an old hypothesis? Curr Opin Genet Dev 21:295-301.
Lambert JC, Heath S, Even G, Campion D, Sleegers K, Hiltunen $\mathrm{M}$, Combarros O, Zelenika D, Bullido MJ, Tavernier B et al. (2009) Genome-wide association study identifies variants at CLU and CR1 associated with Alzheimer's disease. Nat Genet 41:1094-1099.

Lazaris A, Hwang KS, Goukasian N, Ramirez LM, Eastman J, Blanken AE, Teng E, Gylys K, Cole G, Saykin AJ et al. (2015) Alzheimer risk genes modulate the relationship between plasma apoE and cortical PiB binding. Neurol Genet 1:e22.

Li HL, Yang P, Liu ZJ, Sun YM, Lu SJ, Tao QQ, Guo QH and Wu ZY (2015) Common variants at Bin1 are associated with sporadic Alzheimer's disease in the Han Chinese population. Psychiatr Genet 25:21-25.

Lins TC, Vieira RG, Abreu BS, Grattapaglia D and Pereira RW (2010) Genetic composition of Brazilian population samples based on a set of twenty eight ancestry informative SNPs. Am J Hum Biol 22:187-192.

Miller SA, Dykes DD and Polesky HF (1988) A simple salting out procedure for extracting DNA from human nucleated cells. Nucleic Acids Res 16:1215.

Morgan K and Carrasquillo MM (2013) Genetic Variants in Alzheimer's Disease. Springer, New York, 213 p.

Naj AC, Jun G, Beecham GW, Wang L, Narayan B, Buros J, Gallins PJ, Buxbaum JD, Jarvik GP, Crane PK et al. (2011) Common variants in MS4A4/MS4A6E, CD2AP, CD33, and EPHA1 are associated with late-onset Alzheimer's disease. Nat Genet 43:436-441.

O'Brien RJ, Wong PC and Edu R (2011) Amyloid precursor protein processing and Alzheimer's disease. Annu Rev Neurosci 34:185-204.

Pant S, Sharma M, Patel K, Caplan S, Carr CM and Grant BD (2009) AMPH-1/Amphiphysin/Bin1 functions with RME1/Ehd1 in endocytic recycling. Nat Cell Biol 11:1399-410.

Pena SDJ, di Pietro G, Fuchshuber-Moraes M, Genro JP, Hutz MH, Kehdy F de SG, Kohlrausch F, Magno LAV, Montenegro RC, Moraes MO et al. (2011) The genomic ancestry of individuals from different geographical regions of Brazil is more uniform than expected. PLoS One 6:e17063.

Pfrieger FW (2003) Cholesterol homeostasis and function in neurons of the central nervous system. Cell Mol Life Sci 60:1158-1171.

Prince M, Comas-Herrera MA, Knapp M, Guerchet M and Karagiannidou MM (2016) World Alzheimer Report 2016: Improving healthcare for people living with dementia. Alzheimer's Disease International (ADI), London, 140 pp.

Reitz C (2013) Dyslipidemia and the risk of Alzheimer's disease. Curr Atheroscler Rep 15:307.

Rizzi F, Caccamo AE, Belloni L and Bettuzzi S (2009) Clusterin is a short half-life, poly-ubiquitinated protein, which controls the fate of prostate cancer cells. J Cell Physiol 219:314-323.

Schrijvers EMC, Koudstaal PJ, Hofman A and Breteler MMB (2011) Plasma clusterin and the risk of Alzheimer disease. JAMA 305:1322-1326.

Shankarappa BM, Kota LN, Purushottam M, Nagpal K, Mukherjee O, Viswanath B, Varghese $\mathrm{M}$, Bharath $\mathrm{S}$ and Jain $\mathrm{S}$ (2017) Effect of CLU and PICALM polymorphisms on AD risk: A study from south India. Asian J Psychiatr 27:7-11.

Tan L, Wang HF, Tan MS, Tan CC, Zhu XC, Miao D, Yu WJ, Jiang T, Tan L, Yu JT et al. (2016) Effect of CLU genetic 
variants on cerebrospinal fluid and neuroimaging markers in healthy, mild cognitive impairment and Alzheimer's disease cohorts. Sci Rep 6:26027.

Tokuda T, Calero M, Matsubara E, Vidal R, Kumar A, Permanne B, Zlokovic B, Smith JD, Ladu MJ, Rostango A et al. (2000) Lipidation of apolipoprotein E influences its isoform-specific interaction with Alzheimer's amyloid $\beta$ peptides. Biochem J 348:359-365.

Vasiliou V, Vasiliou K and Nebert DW (2009) Human ATPbinding cassette $(\mathrm{ABC})$ transporter family. Hum Genomics 3:281-290.

Vepsäläinen S, Helisalmi S, Mannermaa A, Pirttilä T, Soininen H and Hiltunen M (2009) Topic collections combined risk ef- fects of IDE and NEP gene variants on Alzheimer disease. J Neurol Neurosurg Psychiatry 80:1268-1270.

Yamazaki K, Yoshino Y, Mori T, Yoshida T, Ozaki Y, Sao T, Mori Y, Ochi S, Iga JI and Ueno SI (2017) Gene expression and methylation analysis of ABCA7 in patients with Alzheimer's disease. J Alzheimers Dis 57:171-181.

Yu JT, Tan L and Hardy J (2014) Apolipoprotein E in Alzheimer's disease: An update. Annu Rev Neurosci 37:79-100.

Associate Editor: Mara Hutz

License information: This is an open-access article distributed under the terms of the Creative Commons Attribution License (type CC-BY), which permits unrestricted use, distribution and reproduction in any medium, provided the original article is properly cited. 